\title{
Preemptive and Postoperative Medication Protocols for Root Coverage Combined with Connective Tissue Graft
}

UNIP - Universidade Paulista,

São Paulo, SP, Brazil

Correspondence: Dra. Fernanda Vieira Ribeiro, Av. Dr. Bacelar, 1212, $4^{\circ}$ andar, 04026-002, São Paulo, SP, Brasil. Tel: +55-11-5586-4000. e-mail: ribeirofv@yahoo.com.br
Ana Paula Oliveira Giorgetti, Rafaela de Matos, Renato Corrêa Viana Casarin, Suzana Prese Pimentel, Fabiano Ribeiro Cirano, Fernanda Vieira Ribeiro

\begin{abstract}
This trial evaluated the preemptive and postoperative effect of dexamethasone and ibuprofen on prevention of pain/discomfort, edema and interference in daily life in patients undergoing root coverage combined with subepithelial connective tissue graft (CAF + CTG). Twenty patients were randomly assigned as follows: NSAID Group: $400 \mathrm{mg}$ Ibuprofen 60 min preemptive $+400 \mathrm{mg}$ Ibuprofen postoperative; or SAID Group: $4 \mathrm{mg}$ Dexamethasone 60 min preemptive $+4 \mathrm{mg}$ Dexamethasone postoperative. The postoperative medication was administered 8 and $16 \mathrm{~h}$ post-surgery. Each patient received questionnaires based on a numeric scale (101-point numeric scale rate [NRS-101]) and multiple choice questions (four-point verbal rating scale [VRS-4]) about trans-operative pain/discomfort, hourly for $8 \mathrm{~h}$ after surgery and once a day for three days. A Visual Analogue Scale (VAS) for edema and interference in daily life during the 1st, 2nd, 3rd and 7th day was also answered. The degree of anxiety was rated statistically by the Chi-square test. The MannWhitney and Friedman tests were used for the other questionnaires. The surgery time and number of analgesic pills consumed were compared using Student's t-test. Patients who used dexamethasone presented a trend toward less pain when compared to individuals who ingested ibuprofen, with a significant difference observed $3 \mathrm{~h}$ after the procedure $(p<0.05)$. The use of dexamethasone also promoted less edema until the 2 nd day and lower interference in daily life on the third day when compared with ibuprofen $(p<0.05)$. We concluded that the use of dexamethasone as a preemptive and postoperative medication was more suitable as a drug therapeutic protocol for CAF + CTG.
\end{abstract}

Key Words: anti-inflammatory, pre-emptive drugs, postoperative drugs, periodontal surgery, root coverage.

\section{Introduction}

Gingival recession is defined as the displacement of the soft tissue margin apical to the cement-enamel junction (1) and is a frequent clinical feature in populations with good (2) or poor (3) standards of oral hygiene. It remains a highly prevalent problem (4) and both aesthetics and dentine hypersensitivity are recurrent complaints of patients. Thus, patients commonly ask about treatment options for both single and multiple buccal recession defects.

Several surgical approaches have been proposed for the treatment of these recessions. Among them, the coronally advanced flap (CAF) and the subepithelial connective tissue graft are shown in meta-analyses (5) and several systematic reviews (6-9) to have the greatest potential for recession reduction and complete root coverage (6). Agudio et al. (10), in a longitudinal study (10 to 27 years) showed that the graft subepithelial connective tissue seems to be less susceptible to gingival recession recurrence when compared to other techniques.

Although the connective tissue graft technique presents a good predictability and lower rates of gingival recession recurrence, this therapeutic approach requires a second surgical site, usually the palate, as the donor site graft. Thus, this technique requires a longer surgical time and can cause pain, discomfort and edema in the patient, transand postoperatively. These are common occurrences after periodontal surgery that may appear, mainly in the first $24 \mathrm{~h}(11,12)$. Preemptive medications, aiming to prevent postsurgical pain and discomfort, are of great importance. Different anti-inflammatory medications administered pre-operatively, either non-steroidal anti-inflammatory drugs (NSAIDs) or steroidal anti-inflammatory drugs (SAIDs), are shown to reduce postoperative pain intensity and the need for supplementary analgesics $(1,13)$. The NSAIDs act by blocking the cyclooxygenase (COX) pathway, producing effects on arachidonic acid metabolism and on the inhibition of the synthesis of certain metabolites, such as prostaglandins (PGs) (14). The SAIDs, also defined as corticosteroids, have a higher activity than NSAIDs due to blockade of the A2 phospholipase enzyme, thereby reducing not only the release of PGs, but also other chemical mediators such as leukotrienes and thromboxanes (15), reducing the accumulation of neutrophils and justifying, at least in part, the power of steroidal anti-inflammatory drugs (16).

Some positive results have been shown with the use of SAID and/or NSAID protocols for controlling of 
postoperative pain and edema. Pilatti et al. (17) evaluated the preemptive and post-surgical use of $200 \mathrm{mg}$ celecoxib, a non-steroidal anti-inflammatory drug (one hour before surgery and $12 \mathrm{~h}$ after the first dose), and $4 \mathrm{mg}$ dexamethasone (one hour before surgery and $8 \mathrm{~h}$ after the first dose) for the control of postoperative pain after surgery access for scaling and root planing. According to the authors, both dexamethasone and celecoxib were effective when used as preemptive and post-operative medication.

The preemptive effect of a non-steroidal COX-2 inhibitor with an SAID has also been demonstrated in crown lengthening surgeries, with both anti-inflammatory drug protocols presenting a similar potential for pain and edema relief following periodontal surgery (18).

Even though some studies have shown the advantage of the use of preemptive medications in the control of pain and edema when using NSAIDs or SAIDs, there is no conclusive evidence from clinical trials regarding preemptive analgesic interventions comparing both drug protocols following root coverage combined with subepithelial tissue grafts. To orient and scientifically support the decision-making process for drug protocols proposed to patients, the aim of this study was to evaluate the effect of dexamethasone and ibuprofen used as preemptive medications in combination with their use also in the postoperative period to prevent pain/discomfort, edema and interference in daily life after root coverage combined with subepithelial graft.

\section{Material and Methods}

Study Design

The study design was approved by the Ethics Committee of Paulista University (Protocol \# 142.019). This study was designed as a double-blind randomised parallel study to compare two different preemptive medications in patients requiring root coverage combined with subepithelial graft. All patients received a detailed description of the proposed treatment and gave their written informed consent.

\section{Population Screening}

Twenty patients selected from UNIP Post-graduate Clinic were subjected to complete periodontal and radiographic examination and detailed clinical interview.

The baseline entry criteria included the following: at least one tooth with buccal recession $\geq 2 \mathrm{~mm}$ (classified as Miller's Class I or II) (19) which needed to be submitted to periodontal surgery for root coverage, full-mouth plaque score (FMPS) and full-mouth bleeding score (FMBS) $<20 \%$, tooth vitality and absence of grooves, irregularities, caries, or restorations in the area to be treated.

Patients who were pregnant or lactating, had any conditions that contra-indicated the use of the medications in the study or received medications, were excluded from the study. The exclusion criteria included: pregnancy, lactation, current smoking or smoking within the past 10 years, systemic conditions (e.g. diabetes mellitus, unstable or life-threatening conditions) able to interfere in the pain threshold, analgesics or anti-inflammatory drugs in the previous two.

\section{Pre-Surgical Treatment}

All patients had an initial periodontal treatment which consisted of supragingival calculus removal by one debridement session and two motivation sessions with an interval of 15 days, during which oral hygiene instructions were given with standardised toothbrushes (Oral B Indicator Plus 30; Procter \& Gamble, São Paulo, SP, Brazil) and the Stillman technique in all patients.

Prior to surgery, clinical measurements were reevaluated by the same calibrated examiner (RM). All parameters were measured using a PCP-15 periodontal Probe (Hu Friedy do Brasil, Rio de Janeiro, RJ, Brazil). FMPS (20) and FMBS (21) were calculated after assessing the presence of plaque or bleeding on probing from the bottom of the pocket with a manual probe and calculating the percentage of sites that revealed the presence of plaque or bleeding. Afterwards, those who fulfilled the inclusion criteria were enrolled in the study.

Preemptive medications were administered $60 \mathrm{~min}$ before the surgical procedure being offered by the study investigator prior to the start of surgery. The NSAID COX-1 and -2 inhibitor Group: single doses of $400 \mathrm{mg}$ lbuprofen (Advil, Wyeth, Itapevi, SP, Brazil) or the SAID Group: single doses of $4 \mathrm{mg}$ dexamethasone (Decadron; Aché, Guarulhos, $\mathrm{SP}$, Brazil). The participants did not know which medication they were given.

\section{Sample Size Calculation}

The sample size was calculated using $\alpha=0.05$ and $80 \%$ power. For the variability $(\sigma=S D)$, a value of $10 \mathrm{~mm}$ was used using the data from the NRS-101 (point numeric rate scale) scale in the trans-operative pain/discomfort as the primary outcome variable of this study. The minimum clinically significant value ( $\delta$ ) considered was $15 \mathrm{~mm}$. It was determined that a minimum sample of 7 patients per group would be needed. However, considering that some patients may be lost during follow-up, the number of subjects enrolled per group in this study was 10. A post hoc power analysis of this study was conducted using the primary outcome variable achieving a power value of 1.00 with the present data using the program sample power SPSS 21 (IBM, Armonk, NY, USA).

\section{Surgical Procedures}

Surgical procedures were performed 30 days after the 
initial therapy. Before surgery, intraoral antisepsis was performed with a $0.12 \%$ chlorhexidine rinse solution and extraoral antisepsis was carried out with iodine solution.

Local anaesthesia was obtained with an injectable solution of $2 \%$ lidocaine with epinephrine 1:100,000 (ALPHACAINE, DFL, Rio de Janeiro, Brazil); the patients were treated with the Coronally Advanced Flap (CAF) combined with subepithelial connective tissue graft performed by the same operator (MZC), different from the examiner (RM). The surgical procedure was described previously (8).

\section{Postoperative Care}

At the end of the surgery, patients from each group received two doses of post-operative medications, i.e. 8 and $16 \mathrm{~h}$ post-surgery, as follows: NSAID COX-1 and -2 inhibitor Group: 400 mg lbuprofen or SAID Group: 4 mg dexamethasone. The participants did not know which medication they were given.

All patients received three pills of analgesic medication (Paracetamol $750 \mathrm{mg}$, Medley, Campinas, SP, Brazil) and were instructed to take the medication every $8 \mathrm{~h}$, but only if they experienced pain. Patients were also instructed to quantify analgesic medication taken. For biofilm control, all patients, independent of the treatment received, were instructed to rinse with a $0.12 \%$ chlorhexidine solution twice a day for 7 days. The sutures were removed at 7 days post-surgery.

\section{Evaluated Parameters}

Corah's dental anxiety scale (22) was applied before the surgical procedure due to the fact that stress and dental anxiety vary among patients and may influence patient pain perception. Questionnaires were based on scales used previously by Jensen et al. (23), Peres et al. (18) and Kolbe et al. (24) a 101-point numeric rate scale (NRS-101) and a multiple choice questions (four-point verbal rating scale [VRS-4]), in which patients answered questions about pain

Table 1. Patient and teeth characteristics for both groups at baseline

\begin{tabular}{lcc}
\hline Characteristics & $\begin{array}{c}\text { Dexamethasone } \\
\text { group }\end{array}$ & Ibuprofen group \\
\hline Age (years; mean \pm SD) & $44.30 \pm 12.60$ & $43.40 \pm 15.09$ \\
Sex (\% female) & 60 & 70 \\
Molar teeth (\%) & 6.60 & 6.25 \\
Pre-molar teeth (\%) & 73.40 & 56.25 \\
Canine teeth (\%) & 20 & 37.50 \\
GR (mm; mean \pm SD) & $3.80 \pm 1.48$ & $4.30 \pm 1.49$ \\
\hline
\end{tabular}

No significant inter-group differences were observed at baseline, (Student's t test; $\mathrm{p}<0.05)$; GR: gingival recession. SD: standard deviation. and discomfort hourly for the first $8 \mathrm{~h}$ after surgery and once a day for three days. Moreover, using a $100 \mathrm{~mm}$ horizontal visual analogue scale (VAS), patients answered questions related to the perception of edema and interference in daily life promoted by the surgical procedure within the 1 st, 2 nd, 3rd and 7th day after surgery.

\section{Statistical Analysis}

The Chi-square test was used to statistically assess the degree of anxiety. The Mann-Whitney and Friedman tests were used for the assessment of other questionnaires. The surgical time, number of ingested analgesics and demographic distribution and teeth characteristics were compared using the Student t test.

An experimental level of significance was determined at $5 \%$ for all statistical analyses $(\alpha=0.05)$.

\section{Results}

\section{Demographic Distribution and Teeth Characteristics}

Patient and teeth characterization is demonstrated in Table 1 and no statistical difference ( $p>0.05)$ in an intergroup analysis was demonstrated showing results homogeneity for both groups.

\section{Surgery Time and Number of Consumed Analgesic Pills}

With regard to the surgery time required for the surgical treatment and number of consumed analgesic pills in the postoperative period, no statistically significant differences were observed between groups ( $p>0.05$ ) (Table 2).

\section{Evaluated Parameters Outcome}

Regarding the anxiety level before the surgical procedure, the majority of patients showed mild anxiety levels in both groups, with 7 patients in the SAID Group and 5 in the NSAID Group. Representing the moderate anxiety level, 3 patients belonged to the SAID Group and 2 belonged to the NSAID Group. Although none of the patients in the SAID group demonstrated any intense anxiety level, 3 of them demonstrated it in the NSAID Group. Nonetheless, statistical differences were not observed between groups for any of the anxiety levels ( $>0.05$ ) (Table 3 ).

Table 2. Mean $( \pm \mathrm{SD})$ of surgery time and the number of analgesic consumption after surgery in the SAID Group (Dexamethasone) and NSAID Group (Ibuprofen)

\begin{tabular}{lcc}
\hline Analgesic & $\begin{array}{c}\text { Number of } \\
\text { consumed pills }(\mathrm{n})\end{array}$ & $\begin{array}{c}\text { Surgery } \\
\text { time (min) }\end{array}$ \\
\hline Dexamethasone & $3.5 \pm 3.8 \mathrm{~A}$ & $135.0 \pm 35.2 \mathrm{~A}$ \\
Ibuprofen & $4.0 \pm 4.6 \mathrm{~A}$ & $110.0 \pm 44.7 \mathrm{~A}$ \\
\hline
\end{tabular}

SD: Standard Deviation. No statistical differences were observed between groups (Student's t test), $\mathrm{p}>0.05$. 
Based on the NRS scale, the intensity of pain experienced during the surgical procedure (trans-operative time point) and in the late postoperative period was found to be statistically similar between the SAID and NSAID groups ( $p>0.05)$, except after 3 postoperative $h(3 \mathrm{~h})$, when the SAID Group showed a statistically lower level of pain $(p \leq 0.05)$ than the NSAID Group (Table 4). With respect to the intensity of discomfort (Table 5), the majority of the patients reported intensity 2 (based on the four-point VRS), wherein only intensity 1 and 2 were narrated, with no significant differences observed between the experimental groups at any of the time intervals described $(p>0.05)$. However, for the NSAID Group, only at 3 postoperative days, the intensity 1 discomfort was reported, in contrast to the SAID Group with 5 time intervals and the same intensity of discomfort level post-operatively. Taking into account the edema intensity and the interference in daily

Table 3. Number of patients for each group [SAID Group (Dexamethasone) and NSAID Group (Ibuprofen) regarding the anxiety level before the surgical procedure

\begin{tabular}{|c|c|c|}
\hline Level/Drug & Dexamethasone & Ibuprofen \\
\hline Mild & 7 & 5 \\
\hline Moderate & 3 & 2 \\
\hline Intense & 0 & 3 \\
\hline
\end{tabular}

Table 4. Mean of pain intensity during the transoperative and late postoperative period using the NRS-101 (point numeric rate scale) scale in the SAID Group (Dexamethasone) and NSAID Group (Ibuprofen)

\begin{tabular}{lcc}
\hline Time point & Dexamethasone & Ibuprofen \\
\hline Transoperative & $24.0 \mathrm{Aa}$ & $11.0 \mathrm{Aa}$ \\
$1 \mathrm{~h}$ & $18.5 \mathrm{Aa}$ & $18.5 \mathrm{Aa}$ \\
$2 \mathrm{~h}$ & $10.5 \mathrm{Aa}$ & $13.5 \mathrm{Aa}$ \\
$3 \mathrm{~h}$ & $5.5 \mathrm{Aa}$ & $19.3 \mathrm{Aa}$ \\
$4 \mathrm{~h}$ & $8.5 \mathrm{Aa}$ & $16.3 \mathrm{Aa}$ \\
$5 \mathrm{~h}$ & $3.5 \mathrm{Aa}$ & $14.3 \mathrm{Aa}$ \\
$6 \mathrm{~h}$ & $3.8 \mathrm{Aa}$ & $9.3 \mathrm{Aa}$ \\
$7 \mathrm{~h}$ & $3.2 \mathrm{Aa}$ & $8.3 \mathrm{Aa}$ \\
$8 \mathrm{~h}$ & $2.7 \mathrm{Aa}$ & $7.5 \mathrm{Aa}$ \\
1 day & $2.6 \mathrm{Aa}$ & $14.0 \mathrm{Aa}$ \\
$2 \mathrm{day}$ & $3.5 \mathrm{Aa}$ & $19.5 \mathrm{Aa}$ \\
3 day & $9.5 \mathrm{Aa}$ & $16.0 \mathrm{Aa}$ \\
\hline
\end{tabular}

Means followed by different uppercase letters in rows represent significant inter-group differences by the Mann Whitney test, $\mathrm{p}<0.05$. Means followed by different lowercase letters in columns represent significant intra-group differences by the Friedman test, $\mathrm{p}<0.05$. life (Table 6), both groups showed a reduction over time, and there was a lower degree of edema after 7 days postoperatively than on previous days for the SAID and NSAID groups, especially when comparing first and seventh days $(p \leq 0.05)$. In an intragroup analysis, on the 2 nd postoperative day, the SAID group showed statistically significant less edema than the NSAID group $(p<0.05)$.

\section{Discussion}

Periodontal surgery for root coverage combined with subepithelial connective tissue graft has been shown (68) to be a better option for gingival recession reduction/ resolution, but may lead to a greater postoperative pain and discomfort (10), since two surgical sites are necessary. In order to obtain an adequate control of postoperative morbidity, the choice of medications protocols is essential. In this sense, this is the first study to compare the preemptive and postoperative performance of non-steroidal COX-1 and COX-2 inhibitors with a steroidal anti-inflammatory drug for root coverage combined with subepithelial connective tissue grafts.

Regardless of the pharmacological regimens, both the SAID and NSAID drugs presented a positive final outcome in the control of inflammatory signs and symptoms during the postoperative period. Overall, the results of this study demonstrate that the use of dexamethasone as preemptive and post-operative medication showed a superior effect

Table 5. Mean of discomfort intensity during the trans-operative and late postoperative period using the VRS-101 (four-point verbal rate scale) scale in the SAID Group (Dexamethasone) and NSAID Group (Ibuprofen).

\begin{tabular}{lcc}
\hline Time point & Dexamethasone & Ibuprofen \\
\hline Transoperative & $2 \mathrm{Aa}$ & $2 \mathrm{Aa}$ \\
$1 \mathrm{~h}$ & $2 \mathrm{Aa}$ & $2 \mathrm{Aa}$ \\
$2 \mathrm{~h}$ & $2 \mathrm{Aa}$ & $2 \mathrm{Aa}$ \\
$3 \mathrm{~h}$ & $2 \mathrm{Aa}$ & $2 \mathrm{Aa}$ \\
$4 \mathrm{~h}$ & $2 \mathrm{Aa}$ & $2 \mathrm{Aa}$ \\
$5 \mathrm{~h}$ & $1 \mathrm{Aa}$ & $2 \mathrm{Aa}$ \\
$6 \mathrm{~h}$ & $1 \mathrm{Aa}$ & $2 \mathrm{Aa}$ \\
$7 \mathrm{~h}$ & $1 \mathrm{Aa}$ & $2 \mathrm{Aa}$ \\
$8 \mathrm{~h}$ & $2 \mathrm{Aa}$ & $2 \mathrm{Aa}$ \\
$1 \mathrm{day}$ & $2 \mathrm{Aa}$ & $2 \mathrm{Aa}$ \\
$2 \mathrm{day}$ & $1 \mathrm{Aa}$ & $2 \mathrm{Aa}$ \\
3 day & $1 \mathrm{Aa}$ & $1 \mathrm{Aa}$ \\
\hline
\end{tabular}

Means followed by different uppercase letters in rows represent significant inter-group differences by the Mann Whitney test, $\mathrm{p}<0.05$. Means followed by different lowercase letters in columns represent significant intra-group differences by the Friedman test, $\mathrm{p}<0.05$. 
compared with ibuprofen in controlling pain and discomfort after treatment. Low pain scores were recorded during the entire evaluation period, from 1 hour to 3 days postoperatively for both groups. Thus, preemptive antiinflammatory drugs may prevent hyperalgesia, reducing postoperative pain and discomfort and the consumption of analgesics.

In mucoperiosteal flap surgery for scaling and root planing (17) and in crown lengthening (18), no significant differences for the intensity of pain were demonstrated when both anti-inflammatories (SAID and NSAID) were compared as preemptive and postoperative medications. Steffens et al. (25) also showed no significant difference for pain between the SAID (8 $\mathrm{mg}$ dexamethasone) and NSAID (120 mg etoricoxib) Groups; this was also true for mucoperiosteal flap surgery for scaling and root planing, but the medications were administered only in the preemptive period. On the other hand, Mehra et al. (26) compared different pharmacological regimens using SAIDs and NSAIDs, and demonstrated that the NSAID ibuprofen produced an increased reduction of pain. Patients receiving $600 \mathrm{mg}$ ibuprofen preemptive and postoperative for a week reported increased effectiveness in reducing $\mathrm{PGE}_{2}$ level in urine and saliva when compared to dexamethasone alone after the removal of impacted lower third molars. Besides using the same pharmacological protocols, drug administration routes and the surgery of choice in the studies differs, which may influence the morbidity of the surgeries.

However, there is a trend towards lower pain levels with the use of dexamethasone. Previous research results $(16,27)$ showed that the use of SAID as a preemptive medication was effective in preventing pain after removal of third molars surgeries, which is consistent with the current study, despite the surgery performed and drug dosage showing a better efficacy of dexamethasone; this can be explained by the mechanism of action of this drug, since corticosteroids inhibit the phospholipase A2 enzyme reducing the release of arachidonic acid into leukotrienes and inflammatory cells. Additionally, a lower accumulation of neutrophils may justify, at least in part, the power of SAIDs (28). On the other hand, the NSAIDs act by blocking the cyclooxygenase pathway, producing effects on arachidonic acid metabolism and inhibition of the synthesis of certain metabolites such as prostaglandins (PGs) (29).

Apart from pain, the morbidity of a surgery also takes into account the intensity of edema experienced during the late postoperative period, which showed that the group receiving dexamethasone as preemptive and postoperative medication demonstrated lower edema rates when compared to ibuprofen. Alcântara et al. (30), using linear measurements, demonstrated that dexamethasone controlled edema better than methylprednisolone at all postoperative evaluations. Nonetheless, according to Peres et al. (18), the intensity of edema was similar between the COX-2 inhibitor and SAID groups, which is in accordance with Emery (14). Although the crown lengthening surgeries performed by Peres et al. (18) caused low edema, their follow-up was 4, 8, 12 and 24 $\mathrm{h}$ after surgery, which is different from the current study where the patients were analysed hourly for the first $8 \mathrm{~h}$ after surgery and once a day for the three subsequent days and the seventh day.

It is noteworthy that an important aspect of this study was the assessment of patient anxiety before surgery using an anxiety scale (22), considering that stress and anxiety influence the perception of pain/discomfort, since this is subjective and varies a lot between individuals $(31,32)$. Another important aspect of the present study is associated with the caution used when evaluating the anxiety level before surgery and monitoring the surgery time required for the procedures and number of analgesics consumed in the postoperative period. For all of these evaluated aspects, no differences were observed between the SAID and NSAID groups, confirming the homogeneity of experimental groups and supporting the outcomes obtained in the study. These assessments were not carried out in other studies $(16,17,25-27,30)$, which could affect the interpretation of individual morbidity data.

Unfortunately, both medications present adverse side effects. The NSAID, in this case ibuprofen, is responsible for inhibiting COX-1 and COX-2 as well, which leads to

Table 6. Mean (S.D.) edema intensity and interference in daily life during the late postoperative period using VAS scale in the SAID Group (Dexamethasone) and NSAID Group (Ibuprofen)

\begin{tabular}{lccccc}
\hline Perception & Medication & 1 day & 2 days & 3 days & 4 days \\
\hline \multirow{2}{*}{ Edema } & Dexamethasone & $32.4 \pm 31.6 \mathrm{Aa}$ & $30.4 \pm 32.1 \mathrm{Bab}$ & $22.9 \pm 4.0 \mathrm{Aab}$ & $2.5 \pm 38.3 \mathrm{Ab}$ \\
& Ibuprofen & $52.1 \pm 38.3 \mathrm{Aa}$ & $60.2 \pm 34.4 \mathrm{Aa}$ & $33.9 \pm 33.4 \mathrm{Aab}$ & $11.8 \pm 26.5 \mathrm{Ab}$ \\
Interference & Dexamethasone & $34.5 \pm 28.5 \mathrm{Aa}$ & $29.4 \pm 28.2 \mathrm{Aa}$ & $15.4 \pm 25.7 \mathrm{Bab}$ & $2.4 \pm 4.6 \mathrm{Ab}$ \\
in daily life & Ibuprofen & $53.0 \pm 35.0 \mathrm{Aa}$ & $44.2 \pm 35.9 \mathrm{Aa}$ & $35.3 \pm 33.6 \mathrm{Aab}$ & $6.8 \pm 7.9 \mathrm{Ab}$ \\
\hline
\end{tabular}

Means followed by different capital letters in a row represent significant inter-group differences by the Mann Whitney test, $p<0.05$. Means followed by different non-capital letters in the column represent significant intra-group differences by the Friedman test, $\mathrm{p}<0.05$. 
changes in the gastric mucosa and renal toxicity. The clinical use of dexamethasone has the advantage that it does not act on the cyclooxygenase pathway, thus not promoting changes at the gastric and renal level, but its use should be moderate and rational, for a limited time and dose, because, according to endocrinological analysis, after 5 days of use, the therapy begins to produce immunosuppression, and it may take up to nine months to return to normal levels in some patients (33). However, as anti-inflammatory medications in surgical interventions for root coverage are only required and prescribed for short periods of time, the benefits promoted by a non-steroidal medication protocol would not have the negative impact that this medication promotes when used for longer periods of time, making the indication of this protocol secure and supported from a scientific point of view.

Within the limits of this study, the present study demonstrated that dexamethasone showed better results than ibuprofen to control pain, edema and interference in daily life postoperatively for root coverage combined with connective tissue graft.

\section{Resumo}

Este estudo avaliou o efeito preventivo e pós-operatório de dexametasona e ibuprofeno na prevenção da dor, desconforto, edema e interferência na vida diária, em pacientes submetidos ao recobrimento radicular associado a enxerto de tecido conjuntivo subepitelial (CAF + CTG). Vinte pacientes foram divididos aleatoriamente: Grupo AINES: Ibuprofeno $400 \mathrm{mg} 60 \mathrm{~min}$ antes da cirurgia + lbuprofeno $400 \mathrm{mg}$ no período pós-operatório e Grupo AIES: $4 \mathrm{mg}$ de dexametasona 60 min antes da cirurgia + Dexametasona $4 \mathrm{mg}$ no pós-operatório. A medicação pós-operatória foi administrada $8 \mathrm{e}$ 16 horas pós-cirurgia. Cada paciente recebeu questionários com base na escala numérica NRS-101 (101 pontos numéricos) e perguntas de múltipla escolha (VRS-4) sobre dor / desconforto no periodo transoperatório, de hora em hora durante $8 \mathrm{~h}$ e uma vez por dia durante três dias após a cirurgia. A Escala Visual Analógica (VAS) para análise de edema e interferência na vida diária também foi respondida no $1^{\circ}, 2^{\circ}, 3^{\circ}$ e $7^{\circ}$ dia após a cirurgia. 0 grau de ansiedade foi estatisticamente avaliado pelo teste do Qui-quadrado. Mann-Whitney e Friedman foram utilizados para os demais questionários. Para o tempo de cirurgia e o número de analgésicos consumidos, o teste $t$ de Student foi aplicado. Os pacientes que utilizaram dexametasona apresentaram uma tendência para menores niveis de dor quando comparados aos individuos que ingeriram ibuprofeno, com diferença significativa observada $3 \mathrm{~h}$ após o procedimento cirúrgico $(p<0,05)$. A utilização de dexametasona também promoveu menores niveis de edema até ao segundo dia e menor interferência na vida diária no terceiro dia, quando comparada com o ibuprofeno $(p<0,05)$. Concluiu-se que a utilização de dexametasona como medicamento preventivo e pósoperatório mostra ser mais adequado como protocolo medicamentosos para cirurgias de recobrimento radicular com associação de enxerto de tecido conjuntivo.

\section{References}

1. American Academy of Periodontology. Glossary of Periodontal Terms, 3rd ed. Chicago: The American Academy of Periodontology, 1992.

2. Serino $G$, Wennström $J L$, Lindhe J, Eneroth $L$. The prevalence and distribution of gingival recession in subjects with a high standard of oral hygiene. J Clin Periodontol 1994;21:57-63.

3. Löe $H$, Anerud A, Boysen $H$. The natural history of periodontal disease in man: prevalence, severity, and extent of gingival recession. J Periodontol 1992:63:489-495.

4. Hugoson A, Sjödin B, Norderyd O. Trends over 30 years, 1973-2003, in the prevalence and severity of periodontal disease. J Clin Periodontol 2008;35:405-414.

5. Clauser C, Nieri M, Franceschi D, Pagliaro U, Pini Prato GP. Evidencebased mucogingival therapy. Part 2: Ordinary and individual patient data meta-analyses of surgical treatment of recession using complete root coverage as the outcome variable. J Periodontol 2003;74:741-756.

6. Cairo $F$, Pagliaro $U$, Nieri M. Treatment of gingival recession with coronally advanced flap procedures: a systematic review. J Clin Periodontol 2008;35:136-162.

7. Chambrone L, Sukekava F, Araújo MG, Pustiglioni FE, Chambrone LA, Lima LA. Root-coverage procedures for the treatment of localised recession-type defects: a Cochrane systematic review. J Periodontol 2010;81:452-478.

8. Cortellini P, Pini Prato GP. Coronally advanced flap and combination therapy for root coverage. Clinical strategies based on scientific evidence and clinical experience. Periodontology 2000, 2012;59:158184.

9. Chambrone L, Tatakis DN. Periodontal soft tissue root coverage procedures: a systematic review from the AAP Regeneration Workshop. J Periodontol 2015;86(2 Suppl):S8-S51.

10. Agudio G, Nieri M, Rotundo R, Franceschi D, Cortellini P, Pini Prato GP. Periodontal conditions of sites treated with gingival-augmentation surgery compared to untreated contralateral homologous sites: a 10to 27-year long-term study. J Periodontol 2009;80:1399-1405.

11. Silva RCL, Riera $\mathrm{R}$, Saconato H. Lumiracoxib for acute postoperative dental pain: a systematic review of randomised clinical trials. São Paulo Med J 2011;129:335-345.

12. Piecuch JF. What strategies are helpful in the operative management of third molars? J Oral Maxillofac Surg 2012;70:s25-s32.

13. American Academy of Periodontology. Consensus report on mucogingival therapy. Proceedings of the World Workshop in Periodontics. Ann Periodontol 1996;1:702-706.

14. Emery P. Considerations for non-steroidal anti-inflammatory drug therapy: benefits. Scand J Rheumatol Suppl 1996;105:5-12.

15. Seymour RA, Heasman PA. Drugs and the periodontium. J Clin Periodontol 1988;15:1-16.

16. Laureano-Filho JR, Maurette PE, Allais $M$, Cotinho $M$, Fernandes $C$. Clinical comparative study of the effectiveness of two dosages of dexamethasone to control postoperative swelling, trismus and pain after the surgical extraction of mandibular impacted third molars. Med Oral Patol Oral Cir Bucal 2008;13:129-132.

17. Pilatti GL, André dos Santos F, Bianchi A, Cavassim R, Tozetto CW. The use of celecoxib and dexamethasone for the prevention and control of postoperative pain after periodontal surgery. J Periodontol 2006;77:1809-1814.

18. Peres MF, Ribeiro FV, Ruiz KG, Nociti-Jr FH, Sallum EA, Casati MZ. Steroidal and non-steroidal cyclooxygenase-2 inhibitor antiinflammatory drugs as pre-emptive medication in patients undergoing periodontal surgery. Braz Dent J 2012;23:621-628.

19. PD Jr. A classification of marginal tissue recession. Int J Periodontics Restorative Dent 1985;5:8-13.

20. Ainamo J, Bay I. Problems and proposals for recording gingivitis and plaque. Int Dent J 1975;25:229-235.

21. Muhlemann HR, Son S. Gingival sulcus bleeding-a leading symptom in initial gingivitis. Helv Odontol Acta 1971;15:107-113.

22. Corah NL. Development of a dental anxiety scale. J Dent Res 1969;48:596.

23. Jensen MP, Karoly $P$, Braver $S$. The measurement of clinical pain intensity: a comparison of six methods. Pain 1986;27:117-126.

24. Kolbe MF, Ribeiro FV, Luchesi VH, Casarin RC, Sallum EA, Nociti FH Jr, Ambrosano GM, Cirano FR, Pimentel SP, Casati MZ. Photodynamic therapy during supportive periodontal care: clinical, microbiologic, immunoinflammatory, and patient-centred performance in a splitmouth randomised clinical trial. J Periodontol 2014;85:e277-e86.

25. Steffens JP, Santos FA, Sartori R, Pilatti GL. Preemptive dexamethasone and etoricoxib for pain and discomfort prevention after periodontal 
surgery: a double-masked, crossover, controlled clinical trial. J Periodontol 2010;81:1153-1160.

26. Mehra P, Reebye U, Nadershah M, Cottrell D. Efficacy of antiinflammatory drugs in third molar surgery: a randomised clinical Trial. Int J Oral Maxillofac Surg 2013;42:835-842.

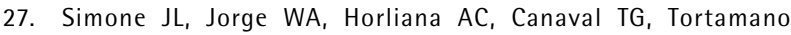
IP. Comparative analysis of pre-emptive analgesic effect of dexamethasone and diclofenac following third molar surgery. Brazilian oral research 2013;27:266-271.

28. Montgomery MT, Hogg JP, Roberts DL, Redding SW. The use of glucocorticosteroids to lessen the inflammatory sequelae following third molar surgery. J Oral Maxillofac Surg 1990;48:179-187.

29. Czock D, Keller F, Rasche FM, Häussler U. Pharmacokinetics and pharmacodynamics of systemically administered glucocorticoids. Clin Pharmacokinet 2005;44:61-98.

30. Alcântara, CE, Falci SG, Oliveira-Ferreira F, Santos CR, Pinheiro ML. Pre-emptive effect of dexamethasone and methylprednisolone on pain, swelling, and trismus after third molar surgery: a split-mouth randomised triple-blind clinical trial. Int J Oral Maxillofac Surg
2014;43:93-98.

31. Philstrom BL, Hargreaves KM, Bouwsma OJ, Myers WR, Goodale MB, Doyle MJ. Pain after periodontal scaling and root planing. J Am Dent Assoc 1999;130:801-807.

32. Curtis JW Jr, McLain JB, Hutchinson RA. The incidence of complications and pain following periodontal surgery. J Periodontol 1985;56:597601.

33. Bystedt H, Nordenram A. Effect of methylprednisolone on complications after removal of impacted mandibular third molars. Swed Dent J 1985;9:65-69.
Received June 30, 2017 Accepted November 6, 2017 